\title{
Diet and Trauma
}

\section{By D. P. Cuthbertson, Rowett Research Institute, Bucksburn, Aberdeenshire}

Before passing to the principal aspect of this subject it is necessary to consider first the train of reactions which are known to set in when a person is subjected to physical trauma, and then to appreciate their bearing on dietary requirements. It is also important to note the influence of the patient's physiological condition at the time of trauma on the subsequent sequence of events. In cases where the trauma has been produced by surgical intent there has generally been a period of bed rest beforehand with some degree of loss of substance through disuse, and in certain cases partial inanition may have been present for some time. In this group the trauma is induced under anaesthesia. In accidental trauma the nutritive state of the organism is generally satisfactory but there is no protection from painful stimuli at the time of, and immediately following, the injury, apart from that which may result from vasovagal collapse.

\section{Nature of response to trauma}

At intervals during the past 20 years I have tried to build up a picture of the postshock metabolic events which I have described as the katabolic response to injury. The period of shock, characterized essentially by depressed cellular metabolism, is initiated by the actual trauma to the cells, direct or indirect. After this the metabolic rate rises with the onset of what has been termed traumatic inflammation (Cuthbertson, 1929, 1931, 1932, 1936, 1942, 1945, 1948). Though this and a variable degree of vasovagal disturbance are the natural defences to prevent further blood loss, it is abundantly clear that any considerable loss of blood or plasma must be made good by the device of replenishing rapidly and adequately that which is lost, for otherwise the patient may die in oligaemic shock and, in any case, convalescence will be delayed.

The observations of Bywaters and his colleagues at the British Postgraduate Medical School, London, first reported by Bywaters \& Beall (194I) (for review see Bywaters, 1944), on the essential lesion of crushing injury bear on the nature of the metabolic response to injury, for in this type of injury muscle necrosis may take place. This may be due to the ischaemia of direct compression or it may be due to ischaemia from interference with the main arterial supply by sudden spasm, thrombosis, rupture or obstruction. Analysis of this necrotic tissue in man and of those from experimentally produced lesions in the rabbit shows that potassium, phosphorus, creatine and acid are lost. Muscle pigment is lost in man, but not in the rabbit, as the latter's muscle contains none. The rabbit shows no renal failure after compression, as may happen in man. If solutions containing myohaemoglobin are injected into rabbits rendered acidotic by ammonium chloride, renal failure will develop and may prove fatal. It is not thought that mechanical blockage of the tubular lumen with pigment plays more than a small part in the general course of this illness, which may prove fatal. Treatment of such cases is confined to immobilization and cooling of the affected limb, the restoration of blood volume and the very early administration of fluid and alkali.

Green and his colleagues (Green, I943; Bielschowsky \& Green, I943; Stoner \& 
Green, 1947, 1949; Green \& Stoner, 1947; Green, Stoner \& Bielschowsky, 1949; Green, Stoner, Hiteley \& Elgin, 1949) have drawn attention to the influx of nucleotides and their breakdown products and to the enhancement of the action of some of these by thromboplastin which had previously been immobilized in the tissues.

I found that patients with moderate or severe physical injury, e.g. the fracture of a long bone, on admission frequently showed a relative or absolute anuria (traumatic anuria) of varying duration during the first $24 \mathrm{hr}$,, and which was possibly due to ischaemia of the renal cortex as described by 'Trueta, Barclay, Daniel, Franklin \& Prichard (1946). The urinary volume was then found to rise slowly and frequently irregularly. The earliest specimens exhibited normal amounts of nitrogen, sulphur and phosphorus, but these values soon rose and between the $4^{\text {th }}$ and 8 th days the maximum was reached. (In a group of postoperative cases such as osteotomies the peak was reached rather earlier.) The nitrogen excreted in the urine was mainly as urea and the sulphur largely as inorganic sulphate. The uric acid also rose and a creatinuria developed (Cuthbertson, 1931). A trace of heat-coagulable protein was occasionally found, particularly at the time of the maximum excretion of nitrogenous catabolites. The nitrogen loss might be as great as $856 \mathrm{~g}$. protein and represent $8 \%$ of the body's protein content, that is much more than could come from the whole of the liver. This metabolic upset can only be partly explained on the basis of disuse atrophy (Cuthbertson, 1929) and this has been confirmed by Keys (1944), Howard, Parson, Stein, Eisenberg \& Reidt (1944), Howard, Winternitz, Parson, Bigham \& Eisenberg (1944) and Beattie (1947). It is not due to anaesthesia (Cuthbertson, 1932).

Usually, though not always, the injury produces a rise in body temperature, its general trend being parallel to that of the basal oxygen consumption and to the urinary nitrogen (Cuthbertson, 1932). After attaining maximal values all the metabolic disturbances decline, though there is evidence that a secondary, smaller, rise may occur. How far this may be due to manipulation of the injured part is not clear.

Although this katabolic reaction is in general proportional to the injury, this relationship is not always clear. Howard, Parson, Stein, Eisenberg \& Reidt (1944) have confirmed my finding that orthopaedic operations result in smaller negative nitrogen balances than accidental injury. A possible explanation of this will be discussed later.

The scale of the loss and the nitrogen: sulphur ratio in the urine during the period of excessive katabolism were suggestive of muscle as the source of the katabolized material. In some experiments on the rat, fracture of a femur under ether anaesthesia produced a comparable picture to that seen in man (Cuthbertson, McGirr \& Robertson, 1939). It was also noted that there was an excessive loss of potassium in the urine paralleling the nitrogen loss but that it was greater than that which would have resulted if potassium was lost from muscle at the same rate as its nitrogen. It was found that the muscles adjacent to the fracture lost relatively more potassium than nitrogen, but the total loss of potassium, like that of nitrogen, was still far greater than could be accounted for by local losses. In these experiments an increase in the creatinuria of the rat resulted, possibly owing to the release of cellular metabolites from the damaged muscles.

The observations of Howard, Parson, Stein, Eisenberg \& Reidt (1944) have shown 
that on the average diets pertaining to their hospitals at that time the negative phase may exist for an average period of $3^{6}$ days.

Lucido (1940), Browne (1942), Cope, Nathanson, Rourke \& Wilson (1943), Taylor, Levenson, Davidson \& Adams (1943), 'Taylor, Levenson, Davidson, Browder \& Lund (1943), and Anderson \& Semeonoff (1944) amongst others (but not Keyser (1948)) have shown the considerable extent of the protein loss in burns, particularly when account is taken of the protein lost in exudate. Clark, Peters \& Rossiter (1945) and Croft \& Peters (1945) have confirmed this experimentally in the rat.

It was suggested by Cuthbertson (1932) that this katabolic response exists in order to render the healing process independent of a supply of food. The sick or injured animal secks security in hiding until it recovers or dies: the innate reparative process must operate irrespective of an exogenous supply of food. 'The increased katabolic processes seem to be conditioned by a reflex mechanism which leads either to the raiding of the body-protein reserves in order to supply endogenously the necessary substrate of amino-acids or peptide groups for the reparative process, or to a mobilization of oxidizable material for the enhanced metabolism of the healing process, or to both processes. 'The fact that there is a parallel rise in the excretion of nitrogen and sulphur, at least in fracture cases, suggests that there is no preferential retention of the sulphurcontaining amino-acids.

When an animal has been depleted of its protein reserves no increase in the rate of loss of body protein occurs on fracture (Munro \& Cuthbertson, 1943), and Madden \& Clay (1945) have shown a somewhat similar effect in acute sterile inflammation. 'The greater the proportion of protein in the diet before and after injury, the greater the nitrogen loss (Munro \& Chalmers, 1945; Peters, 1944; Howard, Winternitz, Parson, Bigham \& Eisenberg, 1944), and Browne, Hoffman, Schenker, Venning \& Weil (1945) have also noted that during the rise in the urinary output of nitrogen after operation or injury the $24 \mathrm{hr}$. urine contained increasing amounts of material which was an II-oxygenated corticosteroid substance that was physiologically active. The daily output of corticosteroid declined in a roughly parallel fashion to the decline in daily urinary nitrogen and reached a normal level at the time when nitrogenous equilibrium was restored. During the phase of positive nitrogen balance the urine contained normal amounts of substances which might have been derived from the adrenal cortex. These workers found that when injury or operation did not produce a rise in nitrogen output in the urine the daily output of corticosteroid in the urine was approximately normal.

Long's (1947) observation that the adrenal cortex shows a marked depletion of its ascorbic-acid content in conditions of stress is of interest and it will be recalled that Stewart, Learmonth \& Pollock (194I) considered that the action of ascorbic acid in haemorrhage is to secure a more adequate supply of oxygen to the tissues. Bourne (1944) has demonstrated that under the conditions of his experiments on guinea-pigs the vitamin is required to produce a sound, strong scar after operation, and Galloway, Garry \& Hitchin (1947) found in vitamin C-deficient guinea-pigs normal healing rates in wounds of cornea and muco-periosteum, but a delay in the healing of ear and skin wounds. The fact that large quantities of the vitamin can be administered after injury without any of the vitamin appearing in the urine until days or even weeks after the 
injury or operation, suggests that the organism is making use of this substance at a rate far exceeding the normal utilization. The quantity retained or destroyed is probably larger than would be used in the actual substance secreted by the adrenal. Doses of $0.5 \mathrm{~g}$./day have been given and have apparently been used rapidly during the period when protein breakdown is rapid. The relation of ascorbic-acid metabolism to that of protein is as yet unknown, but the experiments of Noble \& 'Toby (1948), in which they have induced a depression in the nitrogen output of normal and traumatized rats, is of very great interest. Curiously, ascorbic acid was more effective than various proteins and amino-acids, which might be expected to cause a reduction in nitrogen excretion after trauma. Hallberg (1950) has suggested that the physiological role of ascorbic acid in the adrenal glands is that of oxidizing the steroids present into various active adrenal hormones.

Although Browne (1947) had earlier declared that the changes in nitrogen balance following adrenocorticotrophic hormone (ACTH) are in no way comparable to those seen as the result of injury, there is nevertheless some considerable similarity between certain of these features of the action to $\mathrm{ACTH}\left(\mathrm{Li}, 195^{\circ}\right)$ and the response to injury as described in the previous pages and in the adaptation syndrome described by Selye (1949). Browne, McAlpine \& Hoffman (1948) had specially noted that the marked rise in uric-acid excretion which is relatively greater than that of total nitrogen following ACTH is contrary to that seen in the response to damage. Though this is also the present writer's experience, the points of coincidence are worth further exploration. The experiments of Ingle, Ward \& Kuizenga (1947) and of Noble \& Toby (1948) when viewed together indicate that the adrenal cortex is not essential for the occurrence of protein katabolism after trauma, but that adequate amounts of adrenal cortical extract are necessary in order that the kidney may excrete the nitrogenous end-products. The latter workers found that adrenaline caused an increase in urinary nitrogen but that large, almost toxic doses were necessary to bring about an increase similar to that obtained as the result of trauma.

Noble \& 'T'oby found in a small group of hypophysectomized animals no increase in urinary nitrogen after trauma even when adrenal cortical extract was administered.

Fig. $I$ is an attempt to show the various metabolic paths and hormonal actions following trauma.

Treatment after injury

\section{Diet and trauma}

The tissuc depletion which follows moderate to severe injury is due essentially to two or more of five causes: (I) loss of actual tissue; (2) loss of blood or exudate; (3) loss due to the katabolic response to injury which normally follows injury and subsequent surgical manipulations; (4) loss due to infection ('wound phthisis') if that is superimposed; and (5) disuse, or reflex atrophy.

Where there has been moderate or serious loss of blood or plasma, nutrition may be held to begin with early, rapid and adequate transfusion. Browne et al. (1945) and Kremen (1948) have pointed out that during the katabolic period plasma protein as such administered intravenously does not lead to an immediate rise in nitrogen excretion. Browne $e t$ al. go so far as to say that a patient who is receiving plasma only 


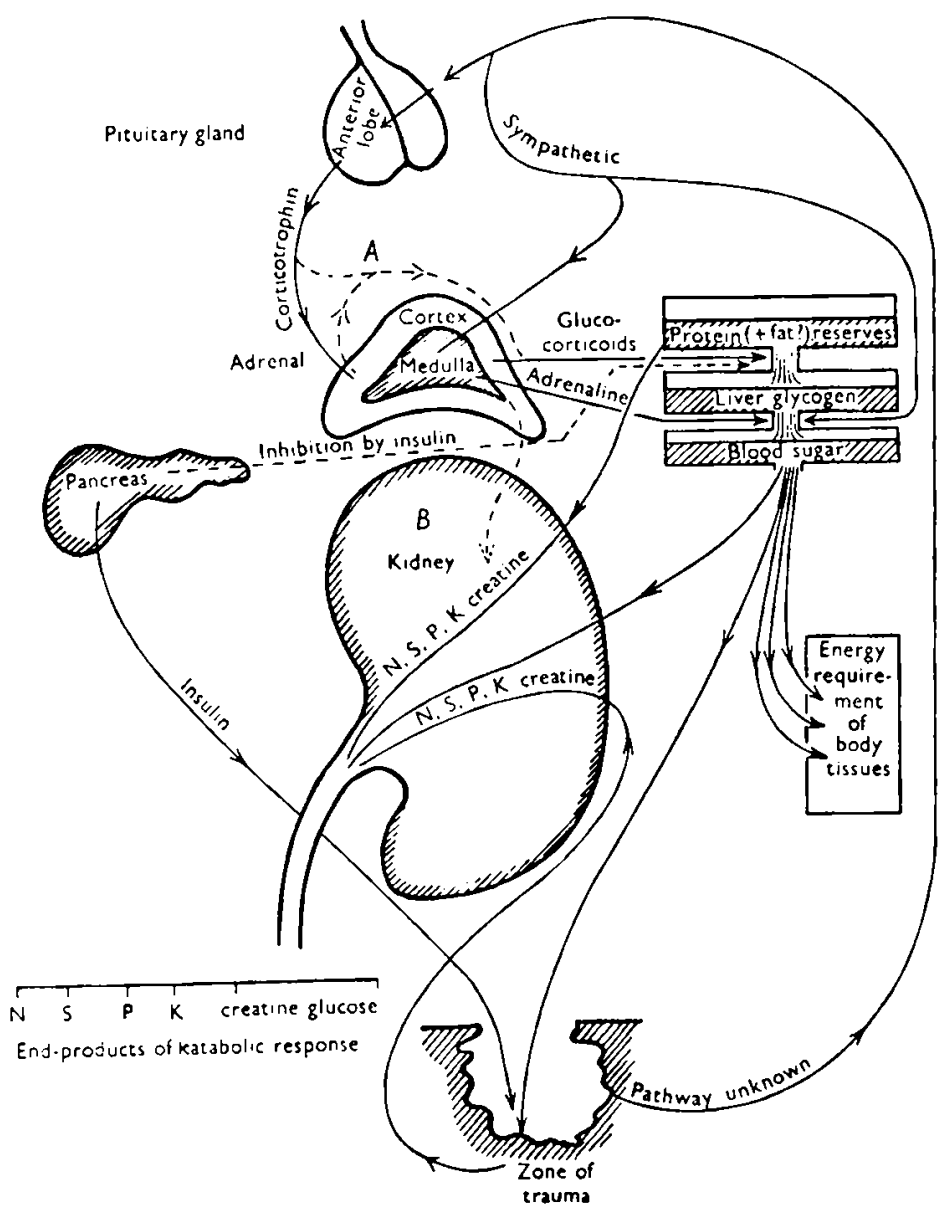

Fig. I. Katabolic response to trauma (after Selye). This figure is an attempt to bring together the sequence of events which constitute the katabolic response to trauma. Through unknown pathways there is at first stimulation of the sympathetic nerve centres in the hypothalamus which induces a rise in blood sugar from liver glycogen. This is due partly to the direct effect of sympathin liberated at nerve endings in liver, and partly to adrenaline discharged as a result of splanchnic stimulation. This mechanism immediately yields a large amount of glucose, but the hyperglycaemia and glycosuria are of limited duration. In addition, through pathways unknown, the anterior lobe of the pituitary is stimulated to produce an excess of corticotrophin which in turn augments adrenal gluco-corticoid secretion. In the absence of the adrenal the effect can still take place provided an extract of cortical substance is supplied, but not necessarily at an increased rate. 'This curious interaction is represented at the point $A$.

The gluco-corticoids promote glycogen formation from protein (and probably fat) in the adequately nourished organism. The evidence for this is an increased excretion of nitrogen, sulphur, phosphorus, potassium and creatine in the urine which is greater than that that could have come from the zone of trauma where similar katabolites (plus myoglobin) appear to be liberated if muscle has been damaged.

The adrenal cortex controls kidney function (indicated by $B$ ) and in its absence there may be a retention of these metabolites in the blood. The ascorbic acid of the adrenal appears to act by oxidizing the steroids present in various active adrenal hormones (Hallberg, r950).

Insulin inhibits (broken arrow) gluconeogenesis from non-sugar reserves and thus antagonizes the gluco-corticoids; yet it also promotes glucose utilization in the area of trauma to promote regeneration of tissue.

In the hypophysectomized animal there is no increase in urinary nitrogen after trauma even when adrenal cortical extract is administered (Noble \& Toby, 1948). 
may be regarded as being starved from this point of view even though he may be mathematically in positive balance and though plasma protein may, of course, contribute to colloidal osmotic pressure and other functions. Despite substantial increase in the intake of a diet rich in protein and calories by patients with moderate or serious injuries I have found that a negative nitrogen balance generally, but not always, exists at the height of the katabolic period following accidental injury (Cuthbertson, I936). The nitrogen loss was, however, mitigated by such procedures, a finding comparable to that described by Peters (1944, 1946) for acute infections. This has been confirmed by Howard, Winternitz, Parson, Bigham \& Eisenberg (1944) and by Grossman, Sappington, Burrows, Lavietes \& Peters (1945) in most cases.

Werner (1948) and Werner, Habif, Randall \& Lockwood (1949) have studied preoperatively the effect of a shift from relatively adequate calories to the lower calorie intake usually given after operation. In their last series the operations involved cholecystectomy, hernia repairs and one colotomy. They have proposed that simple calorie lack explains the postoperative nitrogen loss found following operation uncomplicated by infection. It has been pointed out that their patients were conditioned to hospital before the operation with consequent depletion of their readily katabolizable protein. Similarly, the apparent success of Mulholland, Co Tui, Wright \& Vinci (1943) in achieving a positive nitrogen balance in patients with gastrectomy by means of protein hydrolysates may have been due to the fact that these operations were performed on chronically wasted patients.

Whilst the patient's metabolism is in a katabolic phase, and the extent of the nitrogen loss is largely a measure of the nutritive state of the organism at the time in respect of protein, there seems to be no special reason to worry unduly about this loss in the previously well-nourished subject, provided steps are taken to replace rapidly and adequately the blood or plasma which has been lost by the nature of the accident or operation, and the patient is permitted and gently encouraged to eat to appetite a good diet. One must remember that in the early stages there may be kidney dysfunction and occasionally ulceration of the alimentary tract may result from the trauma. Peters (1948) has written a critical review of the results of those who have tried to push nutriment into patients during the katabolic phase and has pointed out that there is no proof that incoming nitrogen can be utilized to prevent the losses consequent on injury at this time. Howard, Winternitz, Parson, Bigham \& Eisenberg (1944) also observed that injured, but otherwise healthy, persons cannot, or will not, eat more than limited amounts. Hirshfeld, Abbott, Pilling, Heller, Meyer, Williams, Richards \& Obi (1945) found that the early administration of large amounts of protein to burned patients provoked diarrhoea and other untoward symptoms. I personally would decry attempts at tubal feeding unless the nature of the injury or operation requires it or some form of parenteral alimentation. In all injuries, but particularly in severe injuries involving prolonged convalescence, it is necessary to take every reasonable step once the katabolic phase is over, generally by the roth day, to maintain, if not extend, the patient's normal rate of intake in bed so as to make good the tissue losses. Every device which will stimulate appetite should be used. 'This is generally fairly easy if there is no infection. Daily intakes of $3500-4000 \mathrm{Cal}$. and $130 \mathrm{~g}$. or more of protein have been 
used by some groups of workers to prevent or correct as rapidly as possible protein depletion even while the patient is still confined to bed (Mulholland et al. 1943, Lund \& Levenson, 1945); and a daily intake of 2700 Cal. and $100 \mathrm{~g}$. protein has been regarded as the minimum required by such convalescent patients. On the whole, it is perhaps unwise to dogmatize on such matters.

In facio-maxillary injuries and other conditions where the administration of normal forms of food by mouth is precluded, it is best to give the diet as a 'mush' by tube.

Stevenson \& Bensley (1947) have drawn attention to the deficiency that may exist in hospitals between what is planned and what is received by the patient. They also advise in-between meals of milk, milk powder and eggs or, if these are not all available, a high-protein milk shake can be made from a skim milk powder in ordinary milk and with syrup flavourings. It is obvious that the greater the loss of weight and weakness the longer will be the convalescence, if death from inanition does not intervene (Elman, 1944). There is also evidence that depletion of protein may interfere with wound healing and resistance to infection, and predispose to disturbance of gastrointestinal function and liver damage, and to difficulty in the recovery from shock (Mulholland et al. 1943; Whipple \& Madden, 1944; Cannon, 1945; Lund \& Levenson, 1945).

IIigh levels of intake can be reached only by attention to all details necessary to ensure attractive and palatable meals of high nutritive value, and by the use of supplementary feeds. Intravenous protein hydrolysates or tube feeding may be required in some cases where there is inability to ingest, digest and absorb. Though anorexia may make administration of high diet difficult at first, feeding at a high level for a few days is said to lead often to an improvement in appetite (Elman \& Akin 1945; Stevenson, Schenker \& Browne, 1945).

So far the attempts which have been made to stem the katabolic loss of protein have involved ( 1 ) substantial increases in the energy and/or protcin value of the diet, or (2) the administration of amino-acids (e.g. methionine) singly or as mixtures, or of hydrolysates of protein with glucose given intravenously. The evidence is now weighted against methionine having an effect in diminishing the negative nitrogen balance in burns where the previous diet is not deficient in methionine but yet the loss of cystine is quite considerable (Gribble, Peters \& Wakelin, 1947; Sellers \& Best, 1947; Meyer, Hirshfeld \& Abbott, 1947). Emerson \& Binkley (1946) have reported a retention of nitrogen in a few cases in which the ten amino-acids essential for the growth of the rat were given intravenously. An increase in the protein content of the diet did not apparently have a similar effect. But much more evidence is needed, and I am very doubtful if there is any real merit in such lines of parenteral therapy when the patient's ability to ingest and absorb normal dietary proteins is not impaired.

Though there does not appear to be any special need to be concerned about the loss of sulphur, phosphorus and potassium, as these will be looked after if the rest of the diet is well balanced, it may well be that in debilitated patients carly restoration of potassium, and possibly also magnesium, as may be obtained by giving certain meat juices, may play a useful role. The iron requirement may need special attention, particularly where blood loss has not been made good and the diet is largely milk. I think that it is still 
wise to be open-minded about the requirement for vitamin C. Browne (1945) has reported that in his burns and also in fracture cases there may be almost no urinary excretion of ascorbic acid for up to $2 \mathrm{I}$ days after injury, despite a daily intake of both orange juice and up to $700 \mathrm{mg}$. ascorbic acid. Browne relates that a similar increased retention of ascorbic acid after burns has been reported by Johnson, Davidson, Levenson, Lund and Taylor, and that Lowenstein has found a similar retention after certain forms of trauma in animals and also in man. Riboflavin is not so affected but later, when nitrogen is being stored, riboflavin is also retained. Browne could not draw definite conclusions about excretion of aneurin and $N$-I-methylnicotinamide.

\section{Preoperative treatment}

Where the patient is debilitated before operation, the ingestion of a diet adequate in protein and energy should be instituted before the operation, for this realimentation would appear to be as effective, or more effective, preoperatively as when-corresponding increments are made available in the post-traumatic phase, because a condition of nutritional imbalance is usually present in the latter state.

A satisfactory nutritional preparation will undoubtedly extend the benefits of surgery to a group of patients who in the past have often been denied surgery on the basis that they were too poor a risk. Wherever possible, the preoperative steps should involve not only restoration of the water and electrolyte equilibrium, but so far as is possible a high-protein, high-carbohydrate diet fed, where absolutely necessary, by tubal methods. Skim milk powder has been shown to have many advantages as the principal source of protein in the preoperative diet of cases in which there is difficulty in management. Varco (1946, 1947) has described a regime for the preoperative treatment of patients classified as 'poor risks'. The clinical evidence in support of his thesis is certainly worthy of consideration and confirmation trial.

\section{Amino-acid mixtures: intravenous fat}

The controversial aspects of this have been fully covered recently by a group of authors including myself (Peters, 1948; Homburger, 1948; Allison, 1948; Young, 1948; Werner, 1948; Elman, 1948; Cuthbertson, 1948). I am of the opinion that the available evidence in the literature indicates that, provided the energy requirements are covered, nitrogen equilibrium can be attained and the protein requirements of normal adult animals, including man, apparently met by supplying by vein properly prepared hydrolysates of biologically efficient proteins, or by a supply of the essential amino-acids and an additional nitrogen source such as glycine. But in general, the experiments have not gone on long enough to indicate that all the physiological requirements of the adult organism for nitrogen can thereby be met. There is no solid evidence that the intravenous route of administration is superior from the nutritive standpoint to the oral route if this is available: protein hydrolysates by mouth are disagreeable. It is seldom possible to give as a routine more than the equivalent of $75 \mathrm{~g}$. protein and $300-400 \mathrm{~g}$. glucose daily by the intravenous route. If hydrolysates are injected too quickly, nausea and sometimes vomiting may lead to less efficient use of the constituent amino-acids and peptides. Intact food protein by mouth is much more satisfactory and if there has 
been a considerable loss of blood or exudate, whole blood or plasma should immediately be given by vein.

'The rationale for employing amino-acid mixtures parenterally in place of, or along with, intact blood proteins under certain conditions is said to rest more on the necessity to sustain liver function and to maintain a more vigorous nitrogen turnover than on the need of building up a store of protein. We have still no proof of this. 'To save body protein it may seem wise to include all the amino-acids rather than to rely on the essential amino-acids and glycine, since all the twenty commonly occurring aminoacids are required for tissue protein synthesis: but further evidence is needed.

Because of the difficulty of infusing sufficient protein and energy in the infusion fluid it is generally agreed that it is not possible to make good the requirements of the protein-depleted organism entirely by intravenous injection. It is not wise to give fluid containing more than $5 \%$ hydrolysate and $5 \%$ glucose: mixtures of pure aminoacids have been given at $8 \%$. Even these levels necessitate some $4 \mathrm{hr}$. to provide $2000 \mathrm{ml}$. and the patient may be very uncomfortable and demand rest, and may be actually distressed. It is strongly stressed that the calorie requirements are but inadequately met by these intravenous procedures and the recent work of Rose (1949) indicates that with amino-acid mixtures or protein hydrolysates these are greater than one would expect with intact protein. Against this view it is held by some that for short periods of time the glucose intake can be safely limited to $100 \mathrm{~g}$., the rest of the energy needs being met from the adipose tissue.

The use of a stable, finely divided emulsion of fat with a particle size of not more than $2 \mu$. such as that used by Geyer, Mann \& Stare (1948) may be a distinct step forward in meeting calorie requirements. More corroborative evidence is required on this issue. The indications for parenteral feeding are inability to ingest, digest or absorb adequate quantities of food over such a period of time as will jeopardize convalescence and even prejudice the chance of survival.

\section{Conclusion}

In conclusion, the essentials for success in feeding are proper choice of foods and efficient nursing. Nowhere is the co-operation between patient, nurse and doctor more necessary than in severe injuries, particularly extensive burns. If an injured person will take fluids freely and has no gastro-intestinal disorder, it is generally possible to introduce the supplementary quantities of nourishment by substituting highly nutritious for non-nutritious fluids. Milk with skim milk powder, some sugar, and flavouring substances such as coffee, vanilla or chocolate, is an excellent food. A judicious administration of salt or other seasoning may stimulate appetite in cases where the patient shows a disinclination to take fluids freely. Extra nourishment taken in this manner should obviate the need for intravenous treatments except in special cases. In accidental injury there is no special need to worry unduly for the first ro days, though during this period the patient should be permitted and gently encouraged to eat to appetite. During the convalescent period which ensues every step should be taken to improve appetite and the patient's nutritive condition. Where much tissue has been lost there will be a proportionately higher demand for protein. To make the 
maximum use of this protein the energy intake must be adequate. There may also be a special requirement for potassium where there has been a marked katabolic response, but further work is needed on this subject as well as on the requirement for vitamin $\mathrm{C}$.

\section{SUMMARY}

Some of the more general aspects of the response to physical trauma whether due to accident or to surgical intent have been described. It is stressed that a proper appreciation of this response to trauma is necessary in the planning of hospital diets. For those who are due to undergo surgical operation it is strongly advised that within the time limit every effort should be made to improve the nutritive state of the organism and, after the first few days following trauma, advantage should be taken of the heightened synthetic process in the subsequent reconstructive stage to ensure that nothing is lacking in the diet which will ensure optimal convalescence, and every aid which surgery and the ancillary sciences can bring to this process should be sought.

\section{REFERENCES}

Allison, J. B. (1948). Amer. F. Med. 5, 419.

Anderson, A. B. \& Semeonoff, E. (1944). Spec. Rep. Ser. med. Res. Coun., Lond., no. 249, Part 5.

Beattie, J. (1947). Brit. med. F. ii, 8 r3.

Bielschowsky, M. \& Green, H. N. (1943). Lancet, 245, 153.

Bourne, G. H. (1944). Lancet, 246, 688.

Browne, J. S. L. (1942). Conference on Bone and Wound Healing. Transactions of the First Meeting, p. 50. New York: Josiah Macy Jr. Foundation.

Browne, J. S. L. (1945). Conference on Metabolic Aspects of Convalescence Including Bone and Wound Healing. Transactions of the Ninth Meeting, p. 34. New York: Josiah Macy Jr. Foundation.

Browne, J. S. L. (1947). Conference on Metabolic Aspects of Convalescence. Transactions of the Sixteenth Meeting, p. 63. New York: Josiah Macy Jr. Foundation.

Browne, J. S. L., Hoffman, M. M., Schenker, V., Venning, E. H. \& Weil, P. (1945). Conference on Metabolic Aspects of Convalescence Including Bone and Wound Healing. Transactions of the Ninth Meeting, p. 15. New York: Josiah Macy Jr. Foundation.

Browne, J. S. L., McAlpine, H. T. \& Hoffman, M. M. (1948). Conference on Metabolic Aspects of Convalescence. Transactions of the Seventeenth Meeting, p. 148. New York: Josiah Macy Jr. Foundation.

Browne, J. S. L., Schenker, V. \& Stevenson, J. A. F. (1944). F. clin. Invest. $23,932$.

Bywaters, E. G. L. (1944). Э. Amer. med. Ass. 124, 1 103.

Bywaters, E. G. L. \& Beall, D. (1941). Brit. med. F. i, 427.

Cannon, P. R. (1945). F. Amer. med. Ass. 128, 360 .

Clark, E. J., Peters, R. A. \& Rossiter, R. J. (1945). Quart. F. exp. Physiol. 33, I13.

Cope, O., Nathanson, I. J., Rourke, G. M. \& Wilson, H. (1943). Ann. Surg. r17, 937.

Croft, P. B. \& Peters, R. A. (1945). Iancet, 248, 266.

Cuthbertson, D. P. (1929). Biochem. F. 23, 1328.

Cuthbertson, D. P. (1931). Biochem. F. 25, 236.

Cuthbertson, D. P. (1932). Quart. F. Med. I (N.S.), 233.

Cuthbertson, D. P. (1936). Brit. Y. Surg. 23, 505.

Cuthbertson, D. P. (1942). Lancet, 242, 433 .

Cuthbertson, D. P. (1 945). Brit. med. Bull. 3, 96.

Cuthbertson, D. P. (1948). Amer. Y. Med. 5, 879 .

Cuthbertson, D. P., McGirr, J. L. \& Robertson, J. S. M. (1939). Quart. J. exp. Physiol. $29,13$.

Cuthbertson, D. P., Shaw, G. B. \& Young, F. G. (194I). F. Endocrinol. 2, 475.

Cuthbertson, D. P., Webster, T. A. \& Young, F. G. (I94 I). Y. Endocrinol. 2, 459.

Elman, R. (1944). Ann. Surg. 120, 350.

Elman, R. (1948). Amer. Y. Med. 5, 760.

Elman, R. \& Akin, J. T. Jr. (1945). Ann. Surg. 122, 716.

Emerson, K. Jr. \& Binkley, O. F. (1946). F. clin. Invest. 25, I84.

Forsham, P. H., Thorn, G. W., Prunty, F. T. G. \& Hills, A. G. (1948). J. clin. Endocrinol. 8, 15.

Galloway, N. M., Garry, R. C. \& Hitchin, A. D. (1947). Brit. Y. Nutrit. 1, xii.

Geyer, R. P., Mann, G. V. \& Stare, F. J. (r 948). F. Lab. clin. Med. 33, 153. 
Green, H. N. (1943). Lancet, 245, 147.

Green, H. N. \& Stoner, H. B. (1947). Brit. J. exp. Path. 28, 189.

Green, H. N., Stoner, H. B. \& Bielschowsky, M. (r 949). F. Path Bact. 6r, ror.

Green, H. N., Stoner, H. B., Hiteley, H. J. \& Elgin, D. (r949). Clin. Sci. 8, nos. I and 2.

Gribble, M. de G., Peters, R. A. \& Wakelin, R. W. (1947). Y. Physiol. ro6, 36 .

Grossman, C. M., Sappington, T. S., Burrows, B. A., Lavietes, P. H. \& Peters, J. P. (1945). J. clin. Invest. 24, 523 .

Hallberg, L. (1950). Lancet, 258, $35 \mathrm{I}$.

Hirshfeld, J. W., Abbott, W. E., Pilling, M. A., Heller, C. G., Meyer, F., Williams, H. H., Richards, A. J. \& Obi, R. (1945). Arch. Surg. 50, 194.

Homburger, F. (1948). Amer. J. Med. 5, 264.

Howard, J. E., Parson, W., Stein, K. E., Eisenberg, H. \& Reidt, V. (1944). Johns Hopk. Hosp. Bull. 75 , I56.

Howard, J. E., Winternitz, J., Parson, W., Bigham, R. S. Jr. \& Eisenberg, H. (1944). Yohns Hopk. Hosp. Bull. 75, 209 .

Ingle, D. J., Ward, E. O. \& Kuizenga, M. H. (1947). Amer. Y. Physiol. 149, 5 ro.

Keys, A. (1944). Conference on Metabolic Aspects of Convalescence Including Bone and Wound Healing. Transactions of the Seventh Meeting, p. 90 . New York: Josiah Macy Jr. Foundation.

Keyser, J. W. (1948). Ann. Surg. 127,605.

Kremen, A. J. (1948). Surgery, 23, 92.

Li, C. H. (1950). Brit. med. Y. i, 299 .

I cong, C. N. H. (1947). Recent Progr. Hormone Res. r, 99.

Lucido, J. (1940). Ann. Surg. I r. 640.

Lund, C. C. \& Levenson, S. M. (1945). F. Amer. med. Ass. 128, 95.

Madden, S. C. \& Clay, W. A. (1945). F. exp. Med. 82, 65.

Meyer, F. L., Hirshfeld, J. W. \& Abbott, W. E. (1947). Y. clin. Invest. 26, 796.

Mulholland, J. H., Co Tui, F. W., Wright, A. M. \& Vinci, V. J. (1943). Ann. Surg. I17, 512.

Munro, H. N. \& Chalmers, M. I. (1945). Brit. J. exp. Path. 26, 396.

Munro, H. N. \& Cuthbertson, D. P. (1943). Biochem. J. 37, xii.

Noble, R. L. \& Toby, C. G. (1948). Y. Endocrinol. 5, 303.

Peters, J. P. (1944). Fed. Proc. 3, 197.

Peters, J. P. (1946). Ann. New York Acad. Sci. 47, 327.

Peters, J. P. (1948). Amer. F. Med. 5, 100.

Rose, W. C. (1949). Fed. Proc. 8, 546.

Sellers, E. A. \& Best, C. H. (1947). Brit. med. F. i, 522.

Selye, H. (1949). Textbook of Endocrinology, and ed. Montreal, Canada: Acta Endocrinologica Inc.

Stevenson, J. A. F. \& Bensley, E. H. (1947). Lancet, 252, 568.

Stevenson, J. A. F., Schenker, V. \& Browne, J. S. I. (1945). F. Canad. med. Serv. $2,345$.

Stewart, C. P., Learmonth, J. R. \& Pollock, G. A. (1941). Lancet, 240, 818.

Stoner, H. B. \& Green, H. N. (1947). Brit. Y. exp. Path. 28, 127.

Stoner, H. B. \& Green, H. N. (1949). F. Path. Bact. 61, 114.

Taylor, F. H. L., Levenson, S. M., Davidson, C. S. \& Adams, M. A. (1943). New Engl. J. Med. $229,855$.

Taylor, F. H. L., Levenson, S. M., Iavidson, C. S., Browder, N. C. \& Lund, C. C. (1943). Ann. Surg. 18,2 I 5 .

Trueta, J., Barclay, A. E., Danicl, P., Franklin, K. J. \& Prichard, M. M. L. (1946), Lancet, 25 r, 237.

Varco, R. L. (1946). Surgery, r9, 303.

Varco, R. L. (1947). Surg. Gynec. Obstet. 84, 611.

Venning, F. H., de Vries, J. A. \& Herbert, P. H. (1947). Conference on Metabolic Aspects of Convalescence. Transactions of the Sixteenth Meeting, p. I 46 . New York: Josiah Macy Jr. Foundation.

Werner, S. C. (1948). Amer. Y. Med. 5, 749.

Werner, S. C., Habif, D. V., Randall, H. T. \& Lockwood, J. S. (1949). Ann. Surg. 130, 688.

Whipple, G. H. \& Madden, S. C. (r944). Medicine, 23, 2 I5.

White, A. \& Dougherty, T. F. (1946). Ann. N.Y. Acad. Sci. 46, 859.

Young, N. F. (1948). Amer. F. Med. 5, 586 .

\section{Diet and Inborn Errors of Metabolism}

\section{By C. Rimington, Department of Chemical Pathology, University College Hospital Medical School, University Street, London, W.C. I}

The title of my communication imposes upon me rather severe restrictions as to subject. Inborn errors are gene-controlled deviations from the normal and are almost 